J O U R N A OF French and Francophone Philosophy
RE VUE DE LA

philosophie française et de langue française

\title{
Cooking Creoleness
}

\section{Lafcadio Hearn in New Orleans and Martinique}

\section{Valérie Loichot}

Journal of French and Francophone Philosophy - Revue de la philosophie française et de langue française, Vol XX, No 1 (2012) pp 1-21.

\author{
Vol XX, No 1 (2012) \\ ISSN 1936-6280 (print) \\ ISSN 2155-1162 (online) \\ DOI $10.5195 /$ jffp. 2012.537 \\ www.jffp.org
}

\section{(oc) BY-NG-ND}

This work is licensed under a Creative Commons Attribution-Noncommercial-No Derivative Works 3.0 United States License.

\section{ULIS D-Sult}

This journal is operated by the University Library System of the University of Pittsburgh as part of its D-Scribe Digital Publishing Program, and is co-sponsored by the University of Pittsburgh Press 


\title{
Cooking Creoleness
}

\section{Lafcadio Hearn in New Orleans and Martinique}

\author{
Valérie Loichot
}

Emory University

\begin{abstract}
'Anything Creole, Cyrillia; - I want to know what people eat in this country.' She always does her best to please me in this respect.
\end{abstract}

- Hearn, Two Years in the French West Indies, 274

Martinican creolist Raphaël Confiant claims in an unabashed praise of Lafcadio Hearn that the nineteenth century writer "invented what today we might call 'multiple identity' or 'creoleness' [créolité]." ${ }^{1}$ Critic Chris Bongie notes that the word "creolization" appeared for the first time in the English language in Hearn's 1890 novel Youma. ${ }^{2}$ In a letter written to his friend Henry Krehbel in 1883, Hearn himself announces this allegiance to all things creole as he signs "your creolized friend." ${ }^{3}$ These comments identify the nineteenth century thinker not only as a precursor of creoleness, but more importantly, and also surprisingly, as a forerunner of both creoleness and creolization, two related terms that are philosophically unlike in Martinican thought.

The Martinican versions of créolité and creolization have been analyzed tirelessly for the past twenty years. ${ }^{4}$ To summarize, I will simply say that créolité is a concept propelled by linguist Jean Bernabé and writers Raphaël Confiant and Patrick Chamoiseau in their manifesto published simultaneously in French with an English translation by the French leading publisher Gallimard, Éloge de la Créolité / In Praise of Creoleness. ${ }^{5}$ Elsewhere, I have defined the concept of créolité as "a praise for the culturally and racially mixed, a defiance of the pure, accompanied, paradoxically by the threat of essentialism under the cover of an embracing of diversity." ${ }^{6}$ The suffix "-té" (or "-ness") points to the danger of the fixation of créolité into state. Édouard Glissant's creolization, on the other hand, implies a process, a becoming, rather than a fait accompli. ${ }^{7}$ The strange writing of Lafcadio Hearn thus 
oscillates between the two: between a promising dynamism dodging cultural sedimentation and a threatening racial essentialism. ${ }^{8}$ This essay builds on these prior findings to focus specifically on Hearn's act of consumption as it relates to the production of an ideal racial and cultural model of créolité and creolization. ${ }^{9}$

The nineteenth-century Irish-Greek traveler, journalist, novelist, folklorist, Creole linguist, illustrator, libertine, gourmand, and cook Lafcadio Hearn (1850-1904), whom Martinican poet Aimé Césaire famously called a "strange inquirer" ("un questionneur étrange") ${ }^{10}$ spent 10 years in New Orleans (1877-1887) where he wrote and collected, journalistic, culinary, and literary pieces such as La Cuisine Créole: A Collection of Culinary Recipes and Gombo Zhèbes, ${ }^{11}$ a collection of proverbs from 6 different Creoles. From the city of New Orleans, which he called "Gate of the Tropics," Hearn expressed his yearning to move further into the heart of the torrid zone, his desire for "inspiring honey"12 merging aesthetic, culinary, and libidinal consumption in a single gesture. Hearn found his Creole sugary paradise in the city of Saint-Pierre of Martinique ${ }^{13}$ where, between 1887 and 1889, he collected images and proverbs, ingested Creole food and language, and turned mixed-race bodies into sweet aesthetic objects of consumption. His Martinican writings include "A Midsummer Trip to the Tropics," Martinican Sketches," ${ }^{14}$ and the novel Youma: The Story of a West-Indian Slave. ${ }^{15}$

Hearn's journey could be the story of yet another white man, hungry and thirsty for Caribbean land, bodies, and words. ${ }^{16}$ However, his intervention in Martinique unsettles notions of unilateral consumption, racial stability, and cultural property. Clear-cut boundaries between the eater and the consumed, the voyeur and the seen, the "white" and the "colored" are much more fluid than they appear at the outset. Categories are complicated by ethnicity, gender, sexuality, and disability. My central theoretical concern resides in the intersection between racial constructions and the politics of consumption, both erotic and culinary. Hearn's "positive amalgamation" theory of race privileging the "mixed" over the "pure" already highlights the characteristics of Créolité a century before the publication of Bernabé, Confiant, and Chamoiseau's Creole manifesto. For Hearn and for the Martinican Créolistes, métissage represents the cooked, the digestible, while so called "pure" cultural and racial categories occupy the position of the raw or the inedible, to use Levi-Straussian concepts. ${ }^{17}$

This essay reflects on Hearn's indigestible nature, his rejection from his Anglo-Irish family and ultimately from categories of whiteness. In contrast with his own indigestibility, Hearn had a formidable appetite for food and assimilated all. Beyond his frequent literal hunger of a free-lance journalist's struggle to make ends meet, Hearn's desire to ingest "anything Creole" also responded to the urge to fill himself with an identity of adoption. To ingest Creole food meant to become creolized. As he consumed Martinican food, Hearn gave back to Martinique by producing a historical, cultural, and 
economic archive revolving around foodways. This conservation is also associated with the gesture of the thief or the usurper, who built his work on the exploitation (and at times misinterpretation) of a cultural patrimony that did not belong to him. ${ }^{18}$

I then examine Hearn's voyeuristic act of consuming native bodies through the gaze. This form of consumption does not parallel the balanced and equalitarian act of taking and giving involved in the literal act of eating food. Instead, it turns native bodies into consumable goods in a nonreciprocal relationship with the European voyeur. On the theoretical stage as well, distinctions between the eater and the eaten, the original and the secondary, the legitimate and the impostor fail to function as discrete categories. Food, images, sexualized bodies, ideas, and texts circulate independently from an original owner or an indisputable eater. It is never clear who cooks and who gets cooked. Instead, Hearn's intervention in Martinique exposes a digestive machine greater than the eater and the eaten.

\section{Hearn the Indigestible}

For starters, Hearn, far from being an unproblematic "white" and "colonial" traveler, both suffers and benefits from hybridization. ${ }^{19}$ Hearn's Irish family shipped him out to the United States when he was nineteen in part because his name "Lafcadio," derived from the name of the Greek Island of Lefkada, and because of the physical appearance of "the dark child," who earned him the moniker "bastard." The family also expelled the name Lafcadio to simply rename him "Paddy." ${ }^{20}$ Japanese critic Nobukata Miura describes Hearn as a "blanc métis" [a mixed-race White]. ${ }^{21}$ Hearn's visible "ethnic difference" is increased by a physical disability he strictly conceals on his portraits: the partial loss of an eye that occurred during a childhood accident. All authorized portraits of the man are from a profile view or with his eyes closed. According to his optometrist, Hearn "only knew little of the objects he saw, even from less than a meter away." ${ }^{22}$ "In writing and reading he used a glass so large and heavy," Hearn's friend Elizabeth Bisland adds, "as to oblige him to have it mounted in a handle and hold it to his eye like a lorgnette, and for distant observation, he carried an old telescope."23

George Gould - Hearn's ambivalent friend, ophthalmologist, and posthumous autobiographer - confesses: "In a letter to me, written prior to 1889, Hearn says: 'As for me, I have a good deal in me not to thank my ancestors for; and it is a pleasure that I cannot, even if I would, trace myself two generations back, not even one generation on my mother's side. Half these Greeks are mixed with Turks and Arabs - don't know how much of an Oriental mixture I have, or may have." ${ }^{24}$ Hearn situates himself on the side of the Orient, of the mixed, and of troubled origins, and away from whiteness, the West, and clear atavistic inheritance. Gould picks up on Hearn's foreignness, albeit in a less idealistic way, as he describe him 
entering his Philadelphia office upon his return from Martinique: "The poor exotic was so sadly out of place, so wondering, so suffering and shy..." 25 While Hearn views exoticism and rootlessness as an advantage, Gould sees it as an infantilized and weakened position. Hearn is not simply an exotic man, but more radically "an exotic," his whole being reduced to the nominalized adjective. Hearn's perceived foreignness and strangeness renders him indigestible by the white North-American space. His Irishness alone was enough to exclude him from the category of whiteness of nineteenth century North America. ${ }^{26}$

Hearn's birth and personal history - set in islands and archipelagos also define him as a familiar stranger in the Antilles. Geographically and culturally, Hearn belongs to the cultural zones or modes of thinking that Antonio Benítez Rojo defines as the "Repeating Island" or that Édouard Glissant calls "archipelagic thought." Indeed, from his birth island of Lefkada in the Ionian islands, to Ireland, to New Orleans (the cultural island gateway to the Caribbean), to the West Indies, to Japan, the archipelago of his death, Hearn propels himself from island to island. Hearn is close to the Caribbean not only by his "mixed" heritage, but also for his lack of a known past and clear genealogy: culturally and geographically creolized by his archipelagic belonging.

\section{Hearn's Appetite}

Hearn often lived on the edge of hunger. As a young man, Hearn starved in New York, Cincinnati, and New Orleans, where his sporadic work as a journalist did not put enough bread on the table. In his foreword to Hearn's New Orleans Creole Cook Book, Hodding Carter claims that Hearn's collection was written "by a hungry man out of hunger, a physical hunger that seldom was far away." 27 Carter further describes Hearn wandering for several months "in the New Orleans streets, often near starving, as the Cincinnati Commercial did not pay him for his articles on New Orleans." Hearn's hunger is thus first and foremost physical and a matter of survival. The omnipresence of food and eating in his works could be explained by literal hunger. Simply, the abundance of feasts and the profuse listings of dishes on the page would compensate for the lack of food in daily experience. However, stopping at that would restrict food to an act of survival and would deny its potential to build culture and community and its propensity to articulate humanity and creolization. Hearn's struggle with hunger explains only in part his obsession with food.

Stopping at the literal definition of food would also ignore the multilayered aspects of Hearn's consumption. We could identify three aspects of the traveler's hunger: his basic need and desire for literal food, which goes beyond pure physiological satisfaction to reach aesthetic proportions; his hunger for cultural materials such as folktales, proverbs, 
and words, which he ingests and stores in his collections; and finally a libidinal hunger for "native" bodies.

Hearn's career as a food aficionado began in New Orleans. At the end of his stay in the "Creole city" (1877-1887), Hearn published the first and still authoritative collection of Creole New Orleans recipes (Creole Cook Book), which lists hundreds of dishes, including recipes for "bouille-abaisse," "jambolaya," and no less than ten recipes for "gombo." The cookbook is prefaced by Hearn's own commentary on New Orleans Creole diversity ("Cosmopolitan in nature, blending the characteristics of the American, French, Spanish, Italian, West Indian, and Mexican.") The recipes are interspersed with Hearn's sketches and caricatures of New Orleans "types," advice to young housewives, cultural commentaries, and Martinican proverbs or tim-tims. ${ }^{28}$ Through this juxtaposition of Martinican and New Orleans Creole productions, Hearn makes us aware of a common transnational Creole zone, beyond the borders imposed by political national divisions.

Pushing the food experiment further, and showing concern for direct care of the economically poor of New Orleans, Hearn went as far as opening his own restaurant, based on the idea that every dish will cost only five cents. The restaurant on Dryades St., called alternatively "5 Cents Restaurant" and "Hard Times Restaurant," only lasted a few weeks but showed that Hearn's passion for food was not only a selfish enterprise. ${ }^{29}$

Simultaneously to his Creole Cook Book, Hearn publishes Gombo Zhèbes, which already announces Hearn's interest in comparative Creole studies. The collection gathers proverbs from Creoles from Mauritius, Guyana, Martinique, Ayiti, and Louisiana. This collection points to Hearn's hunger for both words and food. As a matter of fact, words and languages become food as they are metaphorized through the unifying image of gumbo, "compounded of many odds and ends," 30 and with indefinite combination possibilities. The association between language and food is explicit in the common description of Creole language in the late nineteenth century: "He had an intense interest in the Negro lore in the Creole countries of the world, and his notebooks were full of quaint Negro proverbs in gombo French. These, he arranged and translated first into correct French and then into English." ${ }^{31}$ Reducing a language to a meal because of its proximity to the tongue runs the risk of turning language into an inarticulate production doomed to be consumed and swallowed. However, Hearn's perception of Creole languages differs from Carter's debasing description. Hearn's association of Creole language and proverbs with gombo aims instead at highlighting the complexity of the language. Indeed, for Hearn, gombo is a highly complex cultural production, an elaborate text that needs to be interpreted, not a jumbled meal destined to be swallowed and reduced to its survival functions: “The literature of 'gombo' has perhaps even more varieties than there are preparations of the esculents above referred to; - the 
patois has certainly its gombo févi, its gombo filé, its 'gombo zhèbes' - both written and unwritten." ${ }^{32}$ Note the plurality, the complexity, and the written and oral characteristics Hearn sees in "gombo speech," in stark contrast with Carter's simplifying qualification of Creole language as "quaint Negro...in gombo French."

While Hearn does not systematically archive Saint-Pierre's recipes in a collection that would parallel his New Orleans cookbook, his Martinican writings are replete with food references. Foodways are presented in their full cultural, social, and historical complexities. During his stay in SaintPierre, Hearn hires an in-house cook and governess, Cyrillia, who introduces him to the subtleties of Creole food. When she takes his breakfast request, Hearn responds: "'Anything creole, Cyrillia; - want to know what people eat in this country." ${ }^{33}$ His culinary hunger therefore entails from the outset a curiosity about cultural specificity. Moreover, the Creole food that Hearn wishes to taste is that of a particular group: “By mangé-créole I refer only to the food of the people proper, the colored population; for the cuisine of the small class of wealthy white chefs is chiefly European, and devoid of local interest." $^{34}$ Therefore, we recognize in Hearn the gourmand, an anthropological drive to study a particular group of culturally and ethnically marked human beings. Interestingly, Hearn gives legitimacy ("the people proper") to the "colored" population of Saint-Pierre.

Chapter Eleven of his Martinican Sketches, entitled "Ma Bonne," devoted to Cyrillia, lists major and minor Martinican dishes such as cocoyage, mabi, calalou, soupe-d'habitant, choux-caraïbes, féroce, sirop-batterie, cousscaye, matêté, macadam, piment-capresse, blaffe, poule-épi-diri, akras, migan-zigname. Hearn systematically situates the dishes and drinks in complete geographical, historical, and economical contexts. Striking are the systematic links he highlights between Martinique and Louisiana. Calalou, for Hearn, "is a gombo soup almost precisely similar to that of Louisiana" (275); he compares "poule-épi-diri" [hen and rice] to "an almost similar [Louisiana] dish ... called jambalaya: chicken cooked with rice" (276). Hearn also reflects on the native origin of ingredients in his discussion of manioc (275) and the African origin of the indispensible Caribbean cooking utensil baton-lélé (273). The precision of his description of fruit (282-85) and fish (278-80) is worthy of Jean-Baptiste Dutertre's exhaustive botanical listing. ${ }^{35}$

Hearn's discussion of food acts as a springboard for an introduction to the subtleties and particularities of Creole language. Through his description of the Creole particularity of the word "sucre," for instance, Hearn demonstrates that Creole is not a "bastard" form of French, as Carter and most of his contemporaries would have it, but a language with specificities, rules, and a grammar of its own: "The word sucre is rarely used in Martinique...the word doux, 'sweet,' is commonly substituted for it. Doux has, however, a larger range of meaning: it may signify syrup...[or] duplicated into doudoux, it means the corossole fruit as well as the 
sweetheart." 36 By incorporating Creole dishes, ingredients, cooking techniques, and eating practices into his Martinican Sketches, Hearn does not simply ingest cultural material for his own digestive sake. He is not only in the position of the taker, but also in that of the giver: his tales constitute an archive that preserves memories of Caribbean foodways. He also occupies the position of the storyteller who links food practices to a larger narrative integrating food into stories of economy, culture, geography, and folklore. His digestion of food and folklore produces not unusable waste, but a fertile ground for future interventions by Martinican authors, as I show later in this paper.

\section{Looking as Eating}

Hearn's obsession with taste and food has a contaminating effect on other senses. The visual realm, usually not as directly associated with food as the senses of smell and taste becomes a site of ingestion of colors, movements, fruit, and young native flesh. By systematically linking his visual descriptions of colored bodies with the metaphor of ingestion, Hearn appears to seek a more complete way of consuming the other. Hearn's contemporary, American poet Walt Whitman describes in similar terms his aesthetic seizing of the world: "All this I swallow, it tastes good, I like it well, it becomes mine." ${ }^{37}$ The metaphor of eating and taste thus allows for an incorporation of the world, a mixing of the self and the world more thorough than visual enjoyment. If Whitman insists on the power of possession that eating brings, "it becomes mine," ingesting an object also brings the power of sameness and communion with the world, or, as we could say, "it becomes me." Eighteenth century French naturalist Buffon describes this blurring of possession and dissolution of self in his Histoire naturelle de l'homme. In an allegorical vision, he imagines an Adam mastering the world through his ingestion of food: "taste gave me a voluptuous feeling; the intimacy of pleasure ["jouissance"] begat the idea of possession; I thought that the substance of these fruits had become my own, and that I had mastered the art of transforming beings." ${ }^{38}$ In this voluptuous primal scene of eating, corporeal pleasure coincides with mastery, control, incorporation, and transformation. In an interesting variation on the Adamic power of inventing the world, it is not the act of naming, but rather, the act of eating which gives the power to transform the world. However, this power over other beings is confusing since, while Buffon's Adamic self acquires power over substances, he also loses his own self in this gesture since the ingested product becomes his own flesh, thus othering it in the process. Absolute power, then, merges with loss of power in the act of ingestion. The ambivalence of the power and loss of self through the act of ingestion is central to Hearn's relation to the Martinican world as well. We could also argue that it is central to all colonial acts or touristic gestures described by an act of ingestion. Eating the other brings about absolute 
power over things ingested, but also unavoidable dissolution of the incorporating self.

The idea of sensual pleasure, control, and loss are also associated in Hearn's gesture, where looking and eating are mutually dependent. Yet, the tension in which they are maintained prevents each one from reaching completion and maintains each of them in a state of desire. ${ }^{39}$ In that, Hearn never reaches the Adamic or colonial power of naming and controlling, never reaches colonial mastery. Instead, his culinary gaze entraps him more than it entraps the seen objects. Additionally, Hearn's colonial gaze could be described as queer, both as in "slightly off" and "homoerotic,"40 a fact that complicates the definition of the colonial gaze as a clear-cut division between traveler and "native," heterosexual European male and exotic female object of desire.

Sexual desire acts as one of the major modes of consumption in Hearn's travelogues. For Adam Rothman, Hearn's interests in the Tropics were "libidinal rather than capital." ${ }^{41}$ Indeed, Hearn's letters reveal frequent sexual contacts with local inhabitants, especially women of color. In his private life, the Irish journalist broke the Southern United States miscegenation laws by marrying - albeit briefly - his mulatto cook, Alethea ("Mattie") Foley. ${ }^{42}$ In New Orleans, Hearn was known to be an avid frequenter of brothels. In a letter to folklorist Henry Krehbiel, he declares: "I eat and drink and sleep with members of the races you detest like the son of Odin that you are. I see beauty here all around me - a strange, tropical intoxicating beauty." 43 Hearn's biographer Gould describes him "with a lot of heathenish and unrestrained appetites." ${ }^{44}$ In spite of Hearn's reputation, or self-acknowledgement of intimacy with natives, and his particular affinity for black and brown bodies, the travelogues of "A Midsummer Trip to the Tropics" and "Martinique sketches" never explicitly refer to sexual contact or actual sexual consumption of bodies. Erotic consumption is for the eyes only.

Despite Hearn's visual impairment or perhaps as an act of compensation against this very disability, his texts contain astonishingly precise and voracious visual descriptions. In his travelogues, the seen bodies are never admittedly touched, yet systematically turned into metaphorical objects of consumption. To give only a few striking examples: "Standing perfectly naked at door-ways, or playing naked in the sun, astonishing children may sometimes be seen - banana-colored or orange babies. " ${ }^{45}$ And as you observe the bare backs, bare shoulders, bare legs and arms and feet, you will find that the colors of flesh are even more varied and surprising than the colors of fruit...But among the brighter half-breeds, the colors, I think, are much more fruit-like; there are banana-tints, lemon-tones, orangehues, with sometimes such a mingling of ruddiness as the pink ripening of a mango." 46 
The description of flesh as fruit in Hearn's texts is surprisingly versatile. The reference to fruit opens up an array of potentialities and an excitement for an impossible classification in set categories. ${ }^{47}$ There are as many skin types as there are Caribbean tropical fruits. Both represent an open-ended list of potentialities. In his "Martinique Sketches," Hearn lists as many as ten different varieties of mangoes, citing only the few ones he has encountered, and thus leaving to the reader's mind the freedom to imagine more: "mango-Bassignac," "Mango-pêche," "mango-vert," "mango-greffe," "mangotine," "mango-quinette," "mango-Zézé," "mango-d'or," "MangoLamentin," and "the superb Reine-Amélie." ${ }^{48}$ Flesh as fruit for Hearn thus opens up an indefinite list of possibilities that defies strict racial categories. These fruit-like skins are also "astonishing," "unheard of," and "unexpected" [inouïs et imprévisibles], the same terms that Glissant uses to describe the offshoots of creolization, a cultural mixing which does not impoverish the mixed products, but which conserves the dynamic diversity of all elements put into contact in the process of creolization. ${ }^{49}$ We should note though that for Glissant, the adjectives "inouïs" and "imprévisibles" are conceptual and are deprived of Hearn's connotations of erotic lust as racial exoticism.

In spite of Hearn's avowed apparent heterosexual preferences in partners, ${ }^{50}$ the versatile descriptions of fruit-like bodies, limbs and flesh applies indiscriminately to women and men, and more specifically to young girls and boys, with a marked preference for boys' bodies. This is in line with the feminization of the colonial native and with the encouraged same-sex relations in the colony. ${ }^{51}$ Robert Young argues that "racial mixing" or what he calls "hybridity" and homosexuality have historically coincided "to become identified with each other, namely as forms of degeneration." ${ }^{2}$ Similarly, for Hearn, the fascination for the hybrid coincides with homoerotic desire. However, for the Greek-Irish traveler, in contrast with the racialist view explained by Young, both métissage and homoeroticism are improved (as opposed to degenerate) forms of human relations. In his travelogues, descriptions of boys playing in the sun and men at work are more sensually infused than descriptions of laundresses, described as "not uncomely, although very dark." ${ }^{53}$

Without fear or exaggerated facts, I can venture to say that the muscular development of the workingmen here is something which must be seen in order to be believed...their muscles stand out with a saliency that astonishes the eye. At a tanning-yard, while I was watching a dozen blacks at work, a young mulatto with the mischievous face of a faun walked by, wearing nothing but a clout (lantcho) about his loins; and never, not even in bronze, did I see such a beautiful play of muscles. A demonstrator of anatomy could have used him for a class model...There are lads wearing nothing, Young boys - yellow and brown little fellows - run in naked... 
These bodies seem to radiate color...it is idyllic, incredible...This flesh does not look like flesh, but like fruit-pulp. ${ }^{54}$

The most striking element of Hearn's vision of Martinican men and boys is the combination of hypersexualization with bi-sexual characteristics. Bodies and faces have the contours of fertility goddesses - "well-rounded limbs," "delicately formed extremities," "grace," and "fruit-pulp flesh" and of super-males: they are defined by the hardness of their limbs as metals and by the "saliency of the muscles." Racial mixing blurs not only racial phenotypes but also gender categories and division between human and animal, in which fabulous beings, such as sphinxes and fauns, in their bisexuality, offer the most astonishing, and hypertrophic, forms of sexuality.

This idyllic universe confuses exoticism in space and nostalgia for a lost time of classical beauty: references to antiquity, Bronze sculpture, and Da Vinci as anatomist paintings abound. An impossible traveling back to the past is made possible by a displacement in space. The fabulous present made of racially mixed boys, allows Hearn to recover a unity that has been lost in time. This nostalgia for a lost aesthetic past harkens back not to an ideal of purity, but to mixing, both racial and sexual.

The image that remains in the reader's mind is the astonishing figure of the young mulatto boy "with the mischievous face of a faun." The adjective "mischievous" refers both to childishness and erotic teasing. Moreover, the figure of the faun blurs not only gender definitions, but also the division between human and animal and evokes a primitive and mythical state of lust and proximity to nature. Métissage for Hearn thus makes visible - if not accessible - a past world, a dream world in which frontiers between white and black, adult and child, male, and female, human and animal constantly shift, blur, and ultimately vanish. ${ }^{55}$

Hearn's gaze is not pure praise and celebration, as we have begun to see. It is voyeuristic at best and violating at worst. Jamaica Kincaid will articulate a century later in A Small Place ${ }^{56}$ the non-reciprocity between the seen and the seer, between the laboring native and the idle tourist or traveler. Idleness, boredom, and hence, aesthetic experience are made possible at the expense of laboring natives who cannot afford the luxury of the traveler.

Hearn seems to find an immense aesthetic and erotic pleasure in the contemplation of people at work. One full chapter of "Martinique Sketches" is devoted to the "Porteuses" or carrier-girls. (77-92) As they return from a fifty kilometer journey with a load of "twenty to thirty pounds" on their heads, Hearn sees only grace and beauty: "Here they come, the girls yellow, red, black. See the flash of the yellow feet where they touch the light! And what impossible tint the red limbs take in the changing glow!" 57 The three colors (yellow, red, black) seem to have directly sprouted from an encyclopedic illustration of human races, perhaps even from a child's 
colorful book of illustrations. The women's bodies, reduced to artistic flashes of color, seem to have lost all embodiment and relationship to their sociohistorical context of labor. The visual jouissance of the viewer stands in stark contrast with the worn-out body of the porteuse, who, as Hearn himself admits, "work[s] from age nine or ten, is worn-out by the end of her twenties, and "cannot even sit down under her burden without risk of breaking her neck." ${ }^{58}$ Mimi Sheller reflects on a similar form of touristic contemplation of laboring bodies. In one of her analyses of tourists observing women involved in the coaling of a steamship, she argues that the laboring bodies "make an interesting 'sight,' and never do these tourists connect the labour they are watching to the fact that it is fueling the mode of transport that has brought them to view this scene." 59

Interestingly, in Hearn's case, the touristic and erotic contemplation of the gaze, which evacuates the pain of the laboring bodies in favor of a blinding beauty and grace, is interrupted by sound. As the scene of beauty from another time enfolds, the scream of the porteuse interrupts Hearn's seeing: "Still, I can hear the voices crying, 'Ah! déchâgé moin vite, chè! moin lasse!'” [Oh! My dear, hurry and unload me, for I am weary!] ${ }^{60}$ Hearn's sense of hearing oddly disrupts his naïve gaze. The heard screams of the porteuse carries a social criticism of his own aesthetic and erotic gaze. The text, through its aural references is full of a life of work, pain, and weariness that the eye won't see.

This blinding beauty exemplifies Suzanne Roussi Césaire's claim, some fifty years later, in her essay "Le grand camouflage," that the tourist and passing traveler cannot see in the Antilles since "il [y] fait certes trop beau...pour $y$ voir" ${ }^{\prime 1}$ (the Antilles are too beautiful to be seen). Hearn's illseeing eye manages to capture young and mixed bodies in a ravenous way, turning the natives into objects of consumption and of aesthetic and erotic pleasure. In a romantic affair he had with an anonymous North-American woman, ${ }^{62}$ Hearn himself defines his appropriation of the young woman as a cannibalistic act: "each night [when] I sat up in your little parlour...[I] acted...the part of a psychical cannibal!" ${ }^{63}$

However, Hearn's physical disability - his severe myopia nearing blindness - has to be taken into account when imagining his position in the Martinican space. Indeed, we should keep in mind the physical restrictions of the onlooker. The Irish visitor had to carry with him a complex apparatus in order to see shapes, muscles, and colors, which made him an unlikely candidate for the part of the sanguinary cannibal. Thus, a description of the author seeing - "Then, you begin to look about you at the faces of the black, brown, yellow people who are watching you curiously from beneath their Madras turbans..." - appears different from what it first seems to be. Hearn, with his near-blindness and telescope in hand, we might imagine, becomes the object of curiosity. Were we to use Frantz Fanon's logic, Hearn's disability would undermine the hierarchy between "white" man and "non- 
whites," for the lack of better words. For Fanon, the statement "then, we had to face the white gaze" ${ }^{\prime 64}$ takes another meaning when the colonial traveler himself becomes the object of curiosity, due to his odd looks and visual disability. ${ }^{65}$ Indeed, for Fanon, between the disabled and the black man emerges a sort of fraternity through lack: "the war amputee tells my brother: 'deal with your color like I deal with my stump; we are both accident victims." "66 Fraternity might not be the best word to describe Hearn's relationship with Martinicans, but his disability must certainly have changed the power dynamics of the gaze. Hearn is this not simply what Mary Louise Pratt terms "the seeing-man," an admittedly unfriendly label for the European male subject...whose imperial eyes passively look out and possess. ${ }^{\prime 67} \mathrm{He}$ is, before all, the object of curiosity of an amused native gaze.

Additionally, the complete absence of description of Hearn's disability in Two Years in the French West Indies (in contrast, references to his nearblindness are frequent in his correspondence ${ }^{68}$ ) also makes us realize that the scene of seeing itself is a fiction, thereby projecting Hearn's racially-mixed paradise onto the realm of the dream. In addition, Hearn's images are greatly enhanced by his imagination or by his memory of travelogues, essays, and poems written on the Antilles, and more generally on exotic places. Thus, we should keep in mind that Hearn's Martinique is composed of the layering of actual sights, memories of readings, and hallucinations. ${ }^{69}$

Hearn's disabled cannibalistic gaze is further made vulnerable through the native eye that strikes back, for instance in the following description of a bread-seller: "Six feet-tall - strength and grace united through her whole figure; with that clear black skin... and the smooth, pleasing solemn features of a sphinx - she looked to me, as she towered there into the gold light, a symbolic statue of Africa." ${ }^{70}$ Even though the unnamed woman is turned into an aesthetic object, an inanimate bronze, her power is nonetheless undeniable. She "towers" over the 5 feet 4 writer with her 6 feet; she represents unity as opposed to the dissolution of the multiple erotic figures populating Hearn's travelogues and boy's dreams. Representing Africa as a continent, she is also linked to the Egyptian and Greek mythology of the sphinx, etymologically, the one who strangles.

The sphinx bread-seller requests one of the "bouts" or "cigars" that Hearn is smoking. The smoked bout being his last, Hearn gives her ten sous, enough to buy twenty bouts. She is thus gaining the power of having many more bouts than him, thereby multiplying the masculine power represented by the cigar. In return, the woman brings him "the finest and largest mango [he] had ever seen, a monster mango." ${ }^{71}$ What happens upon Hearn is "a monster mango," a threatening fruit that can hardly be seized by the eatervoyeur. His mango-colored sexual paradise turns nightmarish. As part of the stipulation of her "gift," the porteuse insists on watching Hearn eat the fruit: "She said she wanted to see me eat it, and sat down on the ground to look on." ${ }^{\prime 72}$ While the man's sucking of the mango and the woman's smoking 
of the cigar evoke in obvious ways heterosexual acts, the reclaiming of the gaze by the porteuse changes the power relation between consumed woman and consuming man.

More than a gift of sheer generosity, the porteuse's command keeps the newly arrived traveler hostage to her own gaze. He is seen while eating an erotically charged fruit, in a sensual manner that involves sucking, smearing, and glistening. Hearn's mouth, now speechless, turns into the erotic feminine fruit he so longed to eat. The Martinican woman also forces the traveler to eat a mango the Caribbean way, i.e., with hands, tongue, and teeth, and without utensils. In doing so, she ingests Hearn into a system of eating Caribbean that incorporates him instead of being incorporated. ${ }^{73}$ In short, she cannibalizes him in her own culinary system by caribbeanizing him. Hearn describes the embarrassing act of eating a mango towards the end of Martinique Sketches: "It is rather slobbery work eating a common mango, in which every particle of pulp is threaded fast to the kernel: one prefers to gnaw it when alone." 74 Two hundred pages after the mango gift, Hearn might revisit the motives of the "kind and grateful" bread-seller.

While perhaps the most comical, the mango episode is just one of many occurrences of gaze reversals. The most threatening looks interestingly come from the East Indians Hearn encounters. In Trinidad, Hearn describes

...a little coolie temple. A few weary Indian laborers slumber in its shadow; pretty naked children...are playing with a white dog... Painted over the wall surface....are extraordinary figures of gods and goddesses. They have several pairs of arms, brandishing mysterious things... While I am looking at these things, one coolie after another wakes up (these men sleep lightly) and begins to observe me almost as curiously, and I fear much less kindly, than I have been observing the gods. ${ }^{75}$

The threatening - and altogether naïve - gaze of the violating watcher reifying humans and gods ("While I am looking at these things") is suddenly overcome by fear. A page later, the threatening eyes of an East Indian child spoil her beauty: "These eyes...have the dark and splendid flame of the eyes of... a bird of prey." ${ }^{76}$ The violator becomes violated by the return of the gaze of a toddler girl, "a little darling just able to walk." As opposed to the infantilized grown women "of colour," the East-Indian toddler introduces a great threat. Not unlike in Barbadian Kamau Brathwaite's model, the East-Indian occupies the position of the inassimilable subject who resists the process of creolization. ${ }^{77}$ To use Zita Nunes's expression in her Cannibal Democracies, the East-Indian constitutes the "remainder," the excess, that which the national body cannot assimilates and excretes. ${ }^{78}$

While the violence of Hearn's stare is undeniable, his gaze, instead of establishing a clear division between the seer and the seen, blurs the 
definition of the colonial gaze, and of the colonial onlooker. In contrast with another contemporary Creole tale collector, Tulane Professor Alcée Fortier, Hearn's gaze destabilizes the difference between the observer and the observed instead of clearly separating them. To quote only a few of Fortier's crude observations from $1895^{79}$ : "While reading these tales, one must bear in mind that most of them were related to children by childlike people" (ix); "While singing, [the storyteller] writhes in a horrible manner and gesticulates wildly...to the tune of the primitive music" $(x)$; "a race rude and ignorant, but not devoid of imagination and poetical feeling" (ix). While Hearn also often projects naiveté and childishness onto the observed subjects, he often acknowledges his own inferiority, for instance in his failure in relaying tales as well as his Creole friends and neighbors: "I succeeded in getting several dictated to me, so that I could write them; others were written for me by my creole friends, with better success. To obtain them in all their originality and simplicity and naïve humor of detail, one should be able to write them down in short hand as fast as they are related; they lose greatly in the slow process of dictation." ${ }^{80}$ In contrast with Fortier, Hearn acknowledges the superiority of the oral performance of the tale over its written inscription, thereby acknowledging the weakness of his own endeavor.

The vulnerability of the transcriber and traveler is ultimately linked to Hearn's complex relationship to Martinican subjects, and to the opacity of his own self. As opposed to the civilizer's gaze who uses the image of the "native other" to consolidate the self, the frequentation, description and visual absorption of the other ultimately dissolve the borders of the self. For Hearn, exoticism is about self-questioning, a definition foreshadowing Victor's Segalen's notion of exoticism, which he will develop in his 1917 essay. ${ }^{81}$ For Segalen, exoticism is not the flattening and simplifying of the world, such as that of the tourist's vision, which he calls a form of failed exoticism ("une mauvaise attitude exotique"). ${ }^{82}$ Exoticism is the realization of an irreducible and incomprehensible distance: "Exoticism is not the perfect comprehension of an outside of ourselves that we would embrace in ourselves, but instead, the sharp and immediate perception of an eternal incomprehensibility." 83

In Hearn's model as well, the self gets shaped by the "incomprehensibly multiple" character of the Martinican multitude with its whimsical and spectrum-like character. Africanness similarly troubles the borders of the observer's self. As Confiant claims, Hearn "had a tremendous appetite for what he himself defined as the vital energy ${ }^{84}$ of the African race, its lack of hypocrisy, its glorification of the body and dancing." ${ }^{85}$ Bronner confirms Hearn's "need, even compulsion, to be 'absorbed' and 'immersed' in dark corners of the city, and he openly admitted his preference for dark bodies." ${ }^{86}$ Hearn's appetite dissolves not the ingested product but the consumer who loses himself in a desire for the multiple strangeness of the natives. 
Hearn concludes his Martinique sketches with a reflection on the relationship between self and other clearly announcing Segalen's theorization: "But in each of us there lives a mysterious Something which is Self, yet also infinitely more than Self - incomprehensibly multiple - the complex total of sensations, impulses, timidities belonging to the unknown past." ${ }^{87}$ Segalen's - and we might add Hearn's - positive interpretation of the failure to comprehend have directly influenced Glissant's notion of positive opacity. ${ }^{88}$ In Hearn's model, the self gets shaped by the "incomprehensibly multiple" display of the Martinican multitude by a mirroring effect doubled by a process of ingestion. In this process, the consumed object remains intact but the chameleon observer assimilates and adopts the dynamic shape of the multiple other. This blurring of self affected by the "incomprehensibly multiple" world of Martinique puts Hearn in a position of privileged spectator, initiator, and usurper of Créolité.

While Lafcadio Hearn's various modes of ingesting the tropics led to a flirting relationship with its food crystallized in a past vision, Hearn's texts, and Hearn himself, continue to serve as a fertile ground for Martinican poets and Martinican sites. ${ }^{89}$ Martinican writers and urban planners keep incorporating Hearn in their texts and urban landscape. The parking lot centrally located in Fort-de-France, adjacent to the "Place de la Savane" is now named "Parking Lafcadio Hearn." All of the writing members of the Césaire family in their own way honored, ingested, or played with Lafcadio Hearn. Suzanne Césaire's play, Aurore de la liberté, which remains lost to this day, was a rewriting of Hearn's Youma. Aimé Césaire dedicated a poem to the Irish traveler. Most recently (2009), Suzanne and Aimé's daughter Ina Césaire reimagined Hearn's sojourn in Martinique, through the eyes and voice of Cyrilia, Hearn's Martinican cook and governess, who has now become Hearn's story-teller. ${ }^{90}$ Moi, Cyrilia, gouvernante de Lafcadio Hearn, in a title reminiscent of Rigoberta Menchú's biography, reclaims the words and recipes Hearn had taken from her. Cyrilia Magloire, now complete with a last name evoking grandeur ( $m a$ gloire, my glory) is the primary eye and mouth of a dialogic narrative between Cyrilia and her commère, or girlfriend Renélise Belhumeur, for whom a certain Mr. Hearn becomes the object of the dialogue. The recipes Hearn had inserted in his writings are reclaimed as Cyrilia's property: "Le gratin de Christophine de Cyrilia," "Le blaff de Cyrilia," etc. Lafcadio Hearn (the man and his texts) has thus become fodder - and fertilizer - for Martinican writers, just like Hearn had fed on Martinican folklore. While Hearn's ingestion at times stabilizes in essentialism a promising cultural diversity, it is this dynamic movement of complex ingestion of texts and words, this creative and ironic cannibalism, that escapes the pitfalls of créolité, and performs a dynamic creolization or Relation, in the Glissantian sense. In short, the process of combining 
elements from two or more original cultures, which leads not to an impoverishing synthesis, but also to an enriched process, amounting to "more than the sum of its original parts;" an encounter where violently different sources do not blend, but congregate; a creolization that also builds on the lacks, interruptions, and violence of an incomplete narrative and on the relationship of all its parts. Such a relation is performed by Ina Césaire's texts and by all the Martinican interventions on Hearn to come. It is perhaps what philosopher René Ménil means when he urges his fellow Martinican citizens to move from a pathological "colonial exoticism," to a "normal exoticism." ${ }^{11}$ What Ménil calls "normal exoticism" would be based on the double gaze of the traveler and the autochtonous inhabitant seeing in eachother their reciprocal strangeness: "Je suis pour lui étranger comme il est pour moi étranger: il a de moi une vision exotique et j'ai de lui une vision exotique. Il ne peut en être autrement" [I am to him a stranger like he is a stranger to me: he has an exotic vision of me like I have an exotic vision of him. There's no other way]. ${ }^{92}$

${ }^{1}$ Introduction to Two Years in the French West Indies (New York: Interlinks Books, 2001), xii.

2 "What I propose to do here is look at two opposed but nonetheless genealogically-related visions of the creolization process, one 'colonial,' the other 'postcolonial.' I will begin by examining the varying uses of the word 'creole' in Lafcadio Hearn's novel Youma, where (if we are to believe the OED) the word 'creolization' makes its first appearance in an English-language text" (Bongie, "Resisting Memories: The Creole Identities of Lafcadio Hearn and Edouard Glissant," SubStance 26 (3[84]) (1997): 153-78, 154.)

${ }^{3}$ Lafcadio Hearn, Life and Letters, 3 vols. Ed. Elizabeth Bisland (Boston: Houghton Mifflin, 1922), vol. $1,274$.

${ }^{4}$ See, for instance Maryse Condé and Madeleine Cottenet Hage's volume Penser la Créolité (Paris: Karthala, 1995) and Mylène Priam's recent work for reflections on créolité. On creolization, see The Creolization Reader: Studies in Mixed Identities and Cultures, ed. Robin Cohen and Paola Toninato (New York: Routledge, 2009) and The Creolization of Theory, ed. Françoise Lionnet and Shu-mei Shih (Durham: Duke University Press, 2011), 1-33. Silvio Torres-Saillant also offers a comprehensive survey of the field in this volume.

${ }^{5}$ Bernabé, Jean, Patrick Chamoiseau and Raphaël Confiant. Eloge de la Créolité. In Praise of Creoleness (Paris: Gallimard, 1993).

6 Loichot, “Créolité Nineteenth Century Style: Lafcadio Hearn's Vision," Canadian Review of Comparative Literature 38 (1) (2011): 57-69," 57.

${ }^{7}$ For Glissant, creolization is an unpredictable dynamic process, which leads to openness rather than fixity. See for instance his Introduction à une poétique du divers (Paris: Gallimard, 1996, 18-19). 
${ }^{8}$ For an extended reflection on Hearn's relationship to créolité and creolization, and for his simultaneous innovative and retrograde vision of race, see my "Créolité Nineteenth Century Style."

9 The introduction to my forthcoming book, The Tropics Bite Back (University of Minnesota Press, March 2013) reflects on the relationship between racial and cultural mixing and acts of consumption such as assimilation and cannibalism. In it, I argue that assimilation is to métissage what cannibalism is to creolization. As for créolité, it amounts to an arrest of exchanges and flows.

${ }^{10}$ See Césaire’s poem "Statue de Lafcadio Hearn” in Ferrements: poèmes (Paris: Seuil, 1960), 43-44.

${ }^{11}$ Creole Cook Book (New York: Coleman, 1885); Gombo Zhèbes (New York: Coleman, 1885).

${ }^{12}$ Vol. 2, 3.

${ }^{13}$ The city of Saint-Pierre and its 30,000 inhabitants were destroyed by the volcanic eruption of Mount Pelée in 1902, only a few years after Hearn's departure.

${ }^{14}$ The two travelogues are grouped under the title Two Years in the French West Indies referred above.

${ }^{15}$ Lafcadio Hearn, Youma: The Story of a West-Indian Slave (New York: Harpers and Brothers, 1890).

${ }^{16}$ Hearn's relationship to the Caribbean is strikingly similar to Walter Jekyll's, a late $19^{\text {th }}$ century white Jamaica folklorist who was also the patron of Claude McKay. A comparison between the two figures remains to be made. I thank Faith Smith for pointing Jekyll out to me.

${ }^{17}$ For the French anthropologist, the cooked represents the cultural process of food transformation that renders it edible, and ultimately technological and human. See Levi-Strauss "Culinary triangle" in Counihan, Carole and Penny Van Esterik, eds, Food and Culture: A Reader. (New York: Routledge, 1997, 28-35), 29.

${ }^{18}$ See James Arnold's “La Martinique de Lafcadio Hearn: un lieu de mémoire paradoxal," Canadian Review of Comparative Literature 38 (1) (2011): 70-79.

19 The term hybridization is to be understood here in its primary meaning as the product of the crossing between different races.

${ }^{20}$ See Simon Bronner's essay for biographical details in “'Gombo Folkloristics: Lafcadio Hearn's Creolization and Hybridization,” Journal of Folklore Research 42 (2) (2005): 141-84.

21 “Maryse Condé et Lafcadio Hearn, un rendez-vous manqué?” Romanic Review Order, Disorder, and Freedom: An Homage to Maryse Condé 94 (3-4) (May-Nov 2003): 451-56, 455.

22 “As for his right eye, according to Dr. Gould who examined him, 'he had approximately twentyfive dioptries of myopia, to use optician's jargon, and consequently, he knew very little of the appearance of the objects he saw, even within a meter" (http://www.hellocaribbean.com/hello40/lafcadio_hearn.htm). For details on the accident that caused Hearn's near-blindness, see Bronner, “Gombo Folkloristics," 154.

${ }^{23}$ Hearn, Life and Letters, 31.

${ }^{24}$ Original emphasis, 2.

${ }^{25}$ George M. Gould, Concerning Lafcadio Hearn (London and Leipsic: T. Fisher Unwin, 1908), 8.

${ }^{26}$ See Noel Ignatiev's How the Irish Became White (London: Routledge, 2008). 
${ }^{27}$ Carter, Foreword to Creole Cook Book.

${ }^{28}$ The crab recipes, for instance, are illustrated with Martinican proverbs: “ $C$ 'est bon khé crâbe qui lacause li pa tini tête (it is because of its good heart that the crab has no head)." Creole Cook Book, 24.

${ }^{29}$ The advertisement for the restaurant reads: "This is the cheapest eating house in the South. It is neat, orderly, and respectable as any other in New Orleans. You can get a good meal for a couple of nickels. All dishes 5 cents. Everything half the price of the markets." (Carter, Foreword to Creole Cook Book, NP).

${ }^{30}$ Hearn, Gombo Zhèbes, 3.

${ }^{31}$ Carter, Foreword to Creole Cook Book.

32 Hearn, Gombo Zhèbes, 3.

${ }^{33}$ Hearn, Two Years, 274.

${ }^{34}$ Hearn, Two Years, 274-75.

${ }^{35}$ Dutertre (1610-1687) was a Dominican priest, chronicler, and botanist who gave an exhaustive account of Martinican fauna, flora, and human mores in Histoire générale des Antilles habitées par les François (Paris : Jacques Langlois, 1654). See “Les plantes,” 145-254.

${ }^{36}$ Hearn, Two Years, 274.

${ }^{37}$ Whitman, Walt, Complete Poetry and Selected Prose (Boston: Houghton Mifflin, 1959), 51.

${ }^{38}$ Buffon, QEuvres (Paris: Gallimard, Bibliothèque de la Pléiade, 2007), 305

${ }^{39}$ Eating and seeing are two modes of incorporation of the other into the self. As Freud argues in Three Essays on the Theory of Sexuality, "[Incorporation] is the process whereby the subject ... has an object penetrate his body and keeps it "inside" his body. Incorporation constitutes an instinctual aim and a mode of object-relationship, which are characteristic of the oral stage; although it has a special relationship with the mouth and with the ingestion of food, it may also be lived out in relationships to other erotogenic zones and other functions. Incorporation provides a corporeal model for introjection and identification” (Freud, quoted in Zita Nunes, Cannibal Democracy: Race and Representation in the Literature of the Americas (Minneapolis: $U$ of Minnesota P, 2008), 34.

40 As Eric Haralson discusses in Henry James and Queer Modernity (Cambridge: Cambridge UP, 2003), the beginning of the association of the word "queer" with homosexuality is hard to situate precisely. While the OED claims that this meaning first appeared in 1922, Haralson argues that "the queer studies meaning of queer" "was already well established on the street" (7) as early as the late 1800 s. Hence, we need to pay close attention to its use in Hearn's texts.

${ }^{41}$ Rothman, Adam, "Lafcadio Hearn in New Orleans and the Caribbean," Atlantic Studies 5 (2) (Aug. 2008): 265-83, 273.

42 This illegal union cost him his job at the Cincinnati Daily Enquirer on the grounds of "deplorable moral habits" (American Writings, 819). See Bronner for a full account of Hearn and Foley's relationship (161-62).

${ }^{43}$ Bronner, “Gombo Folkloristics," 151 
${ }^{44}$ Gould, Concerning Lafcadio Hearn, xii-xiii. The subversive nature of Hearn's sexual appetite could refer to Hearn's preference for "women of color" (at the time rendered illegal by antimiscegenation laws). Gould might also refer to Hearn's homoerotic tendencies.

${ }^{45}$ Hearn, Two Years, 26.

${ }^{46}$ Hearn, Two Years, 26, my emphasis.

${ }^{47}$ By way of contrast, white Guadeloupean poet Saint-John Perse describes, twenty years after Hearn, the colored servants in terms of fruit associated with death and boredom: "Des faces insonores, couleur de papaye et d'ennui” [Soundless faces, the color of papaya and boredom] (CEuvres complètes. Paris: Gallimard, 1982) 27.

${ }^{48}$ Hearn, Two Years, 285.

49 See Glissant, “Métissage et créolisation” in Discours sur le métissage, identités métisses: en quête d'Ariel, ed. Sylvie Kandé (Paris: L’Harmattan, 1999, 47-53) 50.

${ }^{50}$ To my knowledge, there are no studies of Hearn's homoerotic descriptions. However, his letters to his friend George Gould reveal a deep fondness that seems to go beyond camaraderie: "My most dear Gould -I am really quite lonesome for you, and am reflecting how much more lonesome I shall be in some outrageous equatorial country where I shall not see you any more" (94). Gould's letters are not contained in Hearn's collected correspondence. However, Gould's biography of Hearn (published 4 years after Hearn's death) is troubling on many levels using paternalizing, pity, and defamation. We are left wondering why such a friendship might have turned so sour: “He has been spoken of as a 'great man,' which, of course, he was not ... Deprived by nature, by the necessities of his life, or by conscious intention, religion, morality, scholarship, magnanimity, loyalty, character, benevolence, and other constituents of personal greatness" (Gould, Concerning Lafcadio Hearn, x).

51 Young argues that encouraging same-sex encounters in the colony avoided the hybridity that would emerge from heterosexual reproduction. Moreover, hybridity and homosexuality were often associated because they were both considered manifestations of degeneration (See Colonial Desire: Hybridity in Theory, Culture, and Race, London: Routledge, 1995, 25-26).

${ }^{52}$ Young adds that same-sex intercourse was historically encouraged in the colonial context since it did not imply the threat of the creation of mixed-race children (Colonial Desire, 26).

${ }^{53}$ Hearn, Two Years, 167.

${ }^{54}$ Hearn, Two Years, 27.

55 The image of the faun in Hearn's “A Midsummer Trip to the Tropics" recalls the whimsical fairyland of Shakespeare's A Midsummer Night's Dream.

56 Jamaica Kincaid, A Small Place (Farrar, Straus, and Giroux, 2000).

${ }^{57}$ Hearn, Two Years, 91.

${ }^{58}$ Hearn, Two Years, 80.

${ }^{59}$ Consuming the Caribbean: From Arawaks to Zombies (London: Routledge, 2003), 158.

${ }^{60}$ Hearn, Two Years, 92.

${ }^{61}$ Le grand camouflage: Écrits de dissidence (1941-1945) (Paris: Seuil, 2009) 94. 
${ }^{62}$ Her name has been censured for protection of character. In her 1922 edition, the editor of Hearn's letters, Elizabeth Bisland, acknowledges having deleted certain letters and names in order to respect "the dignity and privacy of the living" (vi).

${ }^{63}$ Hearn, Life and Letters, 98.

${ }^{64}$ Hearn, Two Years, 89.

${ }^{65}$ Garland-Thomson, after the anthropologist Robert Murphy, similarly argues that racial difference and disability creates a sort of equality between the racially different and the disabled, based on their common position of being objected to the stare of strangers: "After becoming a wheelchair user ... Murphy, a white man, finds that women and Blacks look at him ... more openly than before. Blacks, he finds, recognize and greet him as 'fellow outsiders' ... Disability, ... feminizes men, making them socially equal to women and people of color" (Staring: How We Look. Oxford: Oxford UP, 2009) 93-94.

66 "The crippled soldier from the Pacific war tells my brother: 'get used to your color the way I got used to my stomp. We are both casualties" (Black Skin, White Masks, trans. Richard Philcox [New York: Grove Press, 2008], 119).

${ }^{67}$ Imperial Eyes: Travel Writing and Transculturation (London: Routledge, 1992), 7.

${ }_{68}$ "I am very near-sighted, have lost one eye, which disfigures me considerably; and my nearsightedness always prevented the gratification of a natural penchant for physical exercise. I am a good swimmer; that is all” (Letter to Gould, Life and Letters vol. 2, 54).

69 The second-hand anthologizing and archiving of the colonial world is nothing new. From Montaigne, who evokes the cannibals through his "truchement" or translator, to Hegel and Gobineau who talk about Africa and the "New World" through second or third-hand accounts of travelers or gossipers, the Antilles have been represented through the prism of dense sedimentation of texts and fantasy, fictions and lies. Some of these accounts are extraordinarily precise for their encyclopedic rendering of the Caribbean. See for instance Paul Reboux's 1931 Le Paradis des Antilles françaises, in which the author admits: "The pages that follow concern Guadeloupe and Martinique. However, I have never set foot in Martinique or Guadeloupe." ([Paris: Librairie de la Revue Française, 1931], 10) One of Reboux's main sources is Hearn's Two Years, demonstrating the endless sedimentation on which representations of the islands are built.

${ }^{70}$ Hearn, Two Years, 86.

${ }^{71}$ Hearn, Two Years, 86.

72 Hearn, Two Years, 86.

${ }^{73}$ I would like to thank Hanétha Vété-Congolo for pointing out this fact.

${ }^{74}$ Hearn, Two Years, 285.

${ }^{75}$ Hearn, Two Years, 62.

${ }^{76}$ Hearn, Two Years, 63.

${ }^{77}$ E.K. Brathwaite, Contradictory Omens (Kingston: Savacou Publications, 1974), 63.

${ }^{78}$ Zita Nunes, Cannibal Democracy: Race and Representation in the Literature of the Americas, (Minneapolis: University of Minnesota Press, 2008), xvi. 
${ }^{79}$ Alcée Fortier, ed. Louisiana Folktales in French Dialect and English Translation (Boston and NY: Houghton, Mifflin, and Company, 1895).

${ }^{80}$ Hearn, Two Years, 514.

81 "[Exoticism consists in] the intoxication of the subject in conceiving its object; in knowing oneself as different from the subject; in feeling the diverse" (43); and Forsdick on Segalen: "The resultant Aesthetics of [Segalen's] Diversity is one which stresses, however, the ultimate relativity not only of the exotic but also ... of home itself" (Segalen, Victor, Essai sur l'exotisme: une esthétique du divers (Paris: Livre de Poche, 1986), 227. Segalen wrote his Essai sur l'exotisme some twenty year after Hearn's Antillean travelogues. He briefly acknowledges Hearn in a footnote: "Lafcadio Hearn. Better at exoticism [un meilleur exote] than I would have guessed" (62).

${ }^{82}$ Segalen, Essai, 71.

${ }^{83}$ Segalen, Essai, 44.

${ }^{84}$ Note the stark contrast between Hearn and Gobineau. Gobineau associates vitality with the "white race" only. Essai sur l'inégalité des races humaines. 2 vols. (Paris: Firmin Didot, 1853), 216-217.

${ }^{85}$ Confiant, "Introduction," op. cit, xi. As I show here, however, Hearn's desire is not for "Africanness," but rather for a state of spectral and diverse mixing. The African (or Black) is demonized, as I show below.

${ }^{86}$ Bronner, “Gombo Folkloristics," 152.

${ }^{87}$ Hearn, Two Years, 306.

${ }^{88}$ Glissant claims that opacity is not "an imprisonment in an impenetrable autarky, but instead, a subsistence in a non-reductible singularity" (Poétique de la Relation, Paris: Gallimard, 1990, 204). On Segalen's influence on Glissant, see Charles Forsdick's Victor Segalen and the Aesthetics of Diversity: Journeys Between Cultures (Oxford: Oxford University Press, 2000), 9098.

${ }^{89}$ See for instance, Aimé Césaire and René Ménil's “Introduction au Folklore Martiniquais" (Tropiques (4) (1942): 7-11) where the authors credit Hearn for having unearthed and preserved the Martinican folktale of "Yé."

${ }^{90}$ Ina Césaire, Moi, Cyrilia, gouvernante de Lafcadio Hearn (Bordeaux: Elytis, 2009).

${ }^{91}$ Ménil, René. Tracées: identité, négritude, esthétique aux Antilles (Paris: Jean Michel Place, 1999), 20. 